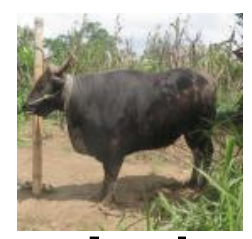

Jurmal

FADET UNUD

\title{
KUALITAS TELUR AYAM ISA BROWN UMUR 95 MINGGU YANG DIBERI RANSUM KOMERSIAL DENGAN TAMBAHAN GRIT KULIT KERANG SEBAGAI SUMBER KALSIUM
}

\author{
Ningsih, A.N.W., G. A. M. K. Dewi.dan,I W. Wijana \\ PS. Sarjana Peternakan, Fakultas Peternakan, Universitas Udayana, Denpasar, Bali \\ E-mail: ayuningsih@ @student.unud.ac.id, Hp 085237942561
}

\begin{abstract}
ABSTRAK
Penelitian ini bertujuan untuk mengetahui kualitas telur ayam Isa Brown umur 95 minggu yang diberi ransum komersial dengan tambahan grit kulit kerang sebagai sumber kalsium. Penelitian dilaksanakan selama 4 minggu di Desa Pesedahan, Kecamatan Manggis, Kabupaten Karangasem Bali dan dilanjutkan analisis sampel di Laboratorium Ternak Unggas Fakultas Peternakan Universitas Udayana. Rancangan yang digunakan rancangan acak lengkap (RAL) terdiri dari 4 perlakuan dan 5 ulangan dimana tiap ulangan terdiri dari 5 ekor ayam. Perlakuan yang diberikan yaitu ayam yang diberikan ransum komersial (P0), ayam yang diberikan ransum komersial ditambah $1 \%$ kulit kerang (P1), ayam yang diberikan ransum komersial ditambah $2 \%$ grit kulit kerang (P2) dan ayam yang diberikan ransum komersial ditambah 3\% grit kulit kerang (P3). Variabel yang diamati meliputi berat telur, indeks telur, tebal kulit telur, berat kulit telur, warna kuning telur, $\mathrm{pH}$ telur dan Haugh Unit. Hasil penelitian menunjukkan bahwa pemberian ransum komersial dengan tambahan grit kulit kerang $1 \%, 2 \%$ dan 3\% sebagai sumber kalsium dapat menghasilkan berat telur, indeks telur, tebal kulit telur, berat kulit telur, warna kuning telur, $\mathrm{pH}$ telur dan haugh unit telur yang berbeda tidak nyata $(\mathrm{P}>0,05)$ daripada ayam yang yang diberikan ransum komersial (P0). Berdasarkan hasil penelitian dapat disimpulkan bahwa pemberian ransum komersial dengan tambahan grit kulit kerang sebagai sumber kalsium tidak dapat meningkatkan berat telur, indeks telur, tebal kulit telur, berat kulit telur, warna kuning telur $\mathrm{pH}$ telur dan Haugh Unit.
\end{abstract}

Kata kunci : kalsium, grit kulit kerang, is a brown, telur

\section{QUALITY OF 95-WEEK-OLD ISA BROWN CHICKEN EGGS GIVEN COMMERCIAL RATIONS WITH ADDITIONAL SHELLS AS CALCIUM SOURCES}

\begin{abstract}
This study aims to determine the quality of 95-week-old Isa Brown chicken eggs fed commercial rations with the addition of clam shells as a source of calcium. The study was conducted for 4 weeks in Pesedahan Village, Manggis District, Karangasem Regency, Bali and continued with sample analysis at the Poultry Laboratory of the Faculty of Animal Husbandry, Udayana University. The design used completely randomized design (CRD) consisted of 4 treatments and 5 replications where each repetition consisted of 5 chickens. The treatments given are chicken given commercial ration (P0), chicken given commercial ration plus $1 \%$ shells (P1), chicken given commercial ration plus $2 \%$ grit shells (P2) and chicken given commercial ration plus $3 \%$ grit conch shells (P3). Variables observed included egg weight, egg index, egg shell thickness, egg shell weight, egg yolk color, egg pH and Haugh
\end{abstract}


Unit. The results showed that the provision of commercial rations with the addition of $1 \%$, $2 \%$ and $3 \%$ shellfish grits as a source of calcium can produce egg weight, egg index, egg shell thickness, egg shell weight, egg yolk color, egg $\mathrm{pH}$ and different egg HaughUnit not significantly $(\mathrm{P}>0.05)$ than chickens that were given commercial rations ( $\mathrm{P} 0)$. Based on the results of the study it can be concluded that the provision of commercial rations with the addition of clam shell grits as a source of calcium can not increase egg weight, egg index, egg shell thickness, egg shell weight, egg yolk color pH and Haugh Unit.

Keywords: calcium, conch shell grits, is a brown, eggs

\section{PENDAHULUAN}

Ayam ras petelur Isa Brown adalah salah satu jenis ayam yang menghasilkan telur dan daging.Telur merupakan produk peternakan yang memberikan sumbangan besar bagi tercapainya kecukupan gizi masyarakat, banyak olahan makanan yang menggunakan telur.Kualitastelur merupakan salah satu pertimbangan konsumen dalam memilih sejumlah telur yang ditawarkan dan kualitas telur merupakan faktor yang penting dalam usaha budidaya ayam petelur, karena kualitas telur yang bagus akan meningkatkan pendapatan peternak akibat dari nilai jual yang tinggi. Kualitas telur dipengaruhi oleh beberapa faktor yaitu salah satunya umur ayam dan konsumsi pakan. Ayam Isa Brown memiliki periode bertelur antara 18-80 minggu, puncak produksi sebesar 95\% pada umur 26 minggu (Hendrix genetics, 2006). Pada umur 80 minggu ayam sudah harus diafkir, karena semakin bertambahnya umur maka kualitas telur akan semakin menurun, hal ini diakibatkan kandungan mineral dalam tubuh ayam semakin berkurang (Hargitai et al., 2011). Ransum mempunyai peranan penting bagi ayam petelur untuk proses reproduksi dan proses produksi. Umumnya peternak ayam menggunakan ransum komersial untuk memenuhi kebutuhan pakan, karena ransum komersial telah disusun sedemikian rupa sehingga memenuhi standar kebutuhan zat pakan yang telah ditetapkan, dan ransum komersial ini banyak tersedia di pasaran.

Saat ini harga pullet dipasaran yang tinggi, para peternak harusmengeluarkan modal yang besar untuk memulainya kembali dan perlu menunggu waktu yang lama untuk ayam memproduksi telur. Dari survei yang dilakukan di peternakan ayam petelur saat ini, peternak masih tetap mempertahankan ayam petelurnya yang memproduksi telur sampai umur 95 minggu namun kualitas telur yang dihasilkan mulai menurun terutama pada pembentukan kulit telur yang kurang optimal sehingga menimbulkan kerugian, Dewi (2010) menyatakan bahwa untuk meningkatkan kualitas telur pada ayam dapat dilakukan dengan meningkatkan kadar kalsium dalam ransum.Kalsium dibutuhkan untuk proses pembentukan kulit telur, ayam petelur umur 20 minggu-afkir memerlukan kalsium sebanyak 3,25-4,25 (SNI, 2006). Kekurangan kalsium akan mengakibatkan kulit telur menjadi tipis dan ayam menjadi lumpuh 
karena tidak terpenuhinya kebutuhan kalsium dalam tubuh ternak maka akan mendeposisi kalsium secara langsung yang diambil dari cadangan kalsium pada tulang tibia (Suprapto et $a l ., 2012$ ). Sumber pakan yang mengandung kalsium yaitu kulit kerang, di Inonesia banyak terdapat limbah kulit kerang kususnya di Kecamatan Manggis dan harganya murah, Kurniasih et al. (2017) menyatakan kandungan grit kulit kerang yaitu Calsium (Ca) sebesar 30\%-40\%, Phospor (P) sebesar 1\%. Reid dan Weber (1976) menyatakan bahwa penggunaan grit kulit kerang lebih efektif untuk meningkatkan kualitas kulit telur apabila dibandingkan dengan penggunaan kapur karena grit kulit kerang dapat mengurai secara mekanik pakan ayam didalam ampela. Penambahan kulit kerang dalam ransum komersial sebanyak 3\% dapat meningkatkan berat telur, tebal kulit telur, berat badan, dan produksi telur (Sultana et al., 2007).

Dari uraian di atas penelitian ini ingin mengetahui bagaimana kualitas telur ayam Isa Brown umur 95 minggu yang diberi ransum komersial dengan penambahan grit kulit kerang sebagai sumber kalsium.

\section{MATERI DAN METODE}

\section{Materi}

\section{Tempat dan waktu penelitian}

Penelitian tentang kualitas telur ayam Isa Brown umur 95 minggu yang diberi ransum komersial dengan tambahan grit kulit kerang sebagai sumber kalsium dilaksanakan di Desa Pesedahan, Kecamatan Manggis, Kabupaten Karangasem, dan pengujian kualitas telur diuji di Laboratorium Ternak Unggas Fakultas Peternakan Universitas Udayana yang berlangsung selama 4 minggu.

\section{Ayam petelur}

Penelitian ini menggunakan ayam petelur Isa Brown dengan umur rata-rata 95 minggu yang diproduksi oleh PT. Wonokoyo Jaya Corporindo.

Grit Kulit kerang

Penelitian ini menggunakan tambahan grit kulit kerang sebagai sumber kalsium, kulit kerang yang digunakan berupa grit kulit kerang dengan ukuran partikel halus yang diproduksi oleh UD. Kembang Sari. Kandungan nutrisi kulit kerang menurut Kurniasih et al. (2017) yaitu Calsium (Ca) sebesar 30 - 40\%, Phospor (P) sebesar $1 \%$.

\section{Ransum dan air minum}

Ransum yang digunakan dalam penelitian ini adalah ransum komersial KLS Super Plus untuk fase layer yang berumur 18-52 minggu yang diproduksi oleh PT. Wonokoyo Jaya 
Corporindo, dengan komposisi kandungan nutrient ransum disajikan dalam (tabel 1), air minum yang digunakan dalam penelitian ini bersumber dari PDAM. Komposisi ransum ayam petelur Isa Brown umur 95 minggu yang digunakan disajikan dalam (tabel 2) dan kandungan nutrien ransum KLS Super Plus PT. Wonokoyo Jaya Corporindo dalam setiap perlakuan disajikan dalam (tabel 3).

\section{Tabel 1 Kandungan nutrien ransum KLS Super Plus PT. Wonokoyo Jaya Corporindo}

\begin{tabular}{lcc}
\hline Kandungan Nutrien $^{1}$ ) & Komposisi $^{1}$ ) & Standar $\left.^{2}\right)$ \\
\hline Energi Termetabolis Kkal/kg & 2900 & $2650(\mathrm{~min})$ \\
Lemak kasar \% & 10,13 & $3,00(\mathrm{~min})$ \\
Protein kasar \% & 18 & $16,00(\mathrm{~min})$ \\
Serat kasar \% & 3,08 & $8,00(\mathrm{maks})$ \\
Kalsium/Ca \% & 3,13 & $3,25-4,50$ \\
Phosfor/P \% & 0,45 & $0,40-0,50$ \\
\hline
\end{tabular}

Keterangan

1) :Ransum PT. Wonokoyo Jaya Corporindo

2) :Standar Nasional Indonesia nutrient ransum ayam petelur umur 50 minggu-afkir SNI (2016)

\section{Peralatan penelitian}

Alat yang digunakan dalam penelitian di kandang terdiri dari kandang battery dengan ukuran panjang $30 \mathrm{~cm}$ x lebar $20 \mathrm{~cm}$ x tinggi $30 \mathrm{~cm}$ terbuat dari kawat besi yang dilengkapi dengan tempat makan dan air minum, timbangan digital kapasitas $7000 \mathrm{~g}$ dengan tingkat ketelitian 1,00 g untuk menimbang telur dan ransum, egg tray dengan kapasitas 30 butir yang digunakan untuk menaruh telur ayam yang telah diambil dalam kandang sesuai dengan perlakuan, polybag sebagai tempat menyimpan ransum.

Alat yang digunakan dalam menguji kualitas telur di laboratorium yaitu $\mathrm{pH}$ meter untuk mengukur pH putih telur dan kuning telur, egg multitester EMT 7300 yang digunakan untuk mengukur kualitas telur secara otomatis dan akurat meliputi berat telur, warna kuning telur, haugh unit, grade telur, micrometer sekrup untuk mengukur ketebalan kerabang, kertas tissue untuk mengelap peralatan yang digunakan, jangka sorong untuk mengukur indeks telur, label untuk menandai telur ayam, baskom plastik untuk menampung telur yang sudah di pecah, dan peralatan tulis untuk menulis data.

\section{Metode Penelitian}

\section{Rancangan penelitian}

Rancangan penelitian yang digunakan dalam penelitian ini adalah rancangan acak lengkap (RAL) dengan 4 perlakuan dan 5 ulangan, dimana tiap ulangan terdiri dari 5 ekor 
ayam petelur umur 95 minggu, total ayam yang digunakan sebanyak 100 ekor. Perlakuan yang diberikan yaitu :

$\mathrm{P}_{0}=$ Ransum komersial

$\mathrm{P}_{1}=$ Ransum komersial ditambah $1 \%$ grit kulit kerang

$\mathrm{P}_{2}=$ Ransum komersial ditambah $2 \%$ grit kulit kerang

$\mathrm{P}_{3}=$ Ransum komersial ditambah $3 \%$ grit kulit kerang

Prosedur penelitian

\section{Pengacakan ayam}

Ayam diletakkan dalam kandang sesuai perlakuan pada setiap ulangan. Penempatan ayam dilakukan dengan teknik pengacakan lengkap dengan terlebih dahulu dilakukan penimbangan bobot badan (dengan catatan bobot badan ayam homogen/koefisien variasi

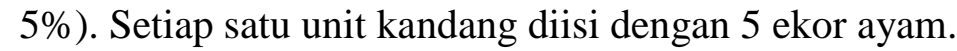

\section{Pencampuran ransum}

Penelitian ini menggunakan ransum KLS Super Plus yang di produksi oleh PT. Wonokoyo Corporindo dengan tambahan kalsium yang bersumber dari grit kulit kerang. Pencampuran ransum dilakukan dengan cara mencampur homogen ransum komersial dengan grit kulit kerang.

Tabel 1 Komposisi ransum ayam petelur isa brown umur 95 mingg $u$

\begin{tabular}{lcccc}
\hline Bahan (\%) & \multicolumn{3}{c}{ Perlakuan } \\
\cline { 2 - 5 } & $\mathrm{P}_{0}$ & $\mathrm{P}_{1}$ & $\mathrm{P}_{2}$ & $\mathrm{P}_{3}$ \\
\hline Ransum komersial & 100 & 100 & 100 & 100 \\
Grit kulit kerang & 0 & 1 & 2 & 3 \\
\hline
\end{tabular}

Keterangan : Ransum KLS Super Plus PT. Wonokoyo Jaya Corporindo 
Tabel 2 Kandungan nutrien ransum KLS Super Plus PT. Wonokoyo

\begin{tabular}{|c|c|c|c|c|c|}
\hline \multirow{2}{*}{ Kandungan nutrien ${ }^{2}$ ) } & \multicolumn{4}{|c|}{ Perlakuan } & \multirow{2}{*}{ Standar $\left.{ }^{3}\right)$} \\
\hline & $\left.\mathrm{P}_{0}{ }^{1}\right)$ & $\mathrm{P}_{1}$ & $\mathrm{P}_{2}$ & $\mathrm{P}_{3}$ & \\
\hline Energi termetabolis $\mathrm{Kkal} / \mathrm{kg}$ & 2900 & 2900 & 2900 & 2900 & $2650(\min )$ \\
\hline Lemak kasar \% & 10,13 & 10,13 & 10,13 & 10,13 & $3,00(\min )$ \\
\hline Protein kasar \% & 18 & 18 & 18 & 18 & $16,00(\mathrm{~min})$ \\
\hline Serat kasar \% & 3,08 & 3,08 & 3,08 & 3,08 & 8,00 (maks) \\
\hline Kalsium/Ca \% & 3,13 & 3,47 & 3,81 & 4,15 & $3,50-4,50$ \\
\hline Phosphor /P \% & 0,45 & 0,46 & 0,47 & 0,48 & $0,40-0,50$ \\
\hline
\end{tabular}

Keterangan :

1): $P_{0}$ : Ransum komersial

$\mathrm{P}_{1}$ : Ransum komersial ditambah $1 \%$ grit kulit kerang

$\mathrm{P}_{2}$ : Ransum komersial ditambah $2 \%$ grit kulit kerang

$\mathrm{P}_{3}$ : Ransum komersial ditambah $3 \%$ grit kulit kerang

2): Ransum komersial PT Wonokoyo

3): Standar Nasional Indonesia nutrient ransum ayam petelur umur 50 minggu-afkir SNI (2016)

\section{Pemberian ransum komersial dan air}

Pemberian ransum dan air kepada ternak ayam diberikan secara ad libitum sesuai perlakuan, yang dilakukan setiap pagi hari jam 08.00 WITA

\section{Pengambilan data telur}

Pengambilan data telur setiap perlakuan dilakukan dengan cara menimbang telur disetiap ulangan yang dilakukan setiap hari, kemudian data telur akan dicari rata-ratanya dengan rumus:

$$
\text { rata }- \text { rata berat telur }=\frac{\text { jumlah berat telur }}{\text { jurrlah telur }}
$$

telur yang mendekati \pm rata-rata berat telur digunakan sebagai sampel dan diuji kualitas telurnya di laboratorium Ternak Unggas Fakultas Peternakan Universitas Udayana setiap hari rabu.

Variabel yang diamati

Dalam penelitian ini variabel yang diamati yaitu kualitas eksterior dan interior dari telur ayam Isa Brown.

a Kualitas Eksterior

1. Berat telur diperoleh dengan menimbang telur sebelum dipecahkan, masing-masing telur ditimbang beratnya menggunakan timbangan digital.

2. Indeks telur dapat diukur menggunakan alat jangka sorong, menurt Suhardi (2013) indeks telur dapat dihitung dengan rumus 


$$
\text { indeks telur : } \frac{\text { lebar telur }}{\text { parjong telur }} \times 100 \%
$$

b. Kualitas Interior

1. Tebal kulit telur diukur menggunakan micrometer yang memiliki ketelitian $0,001 \mathrm{~mm}$, pengukuran tebal kulit telur dilakukan dengan cara pecahkan telur dan bersihkan kulitnya selanjutnya ukur menggunakan alat micrometer.

2. Berat kulit telur diukur dengan cara telur yang sudah dipecahkan lalu ditimbang kulit telurnya menggunakan timbangan digital.

3. Warna kuning telur diukur dengan menggunakan Egg Yolk Colour Fan.

4. $\mathrm{pH}$ telur diukur dengan cara putih dan kuning telur di campur lalu di ukur menggunakan $\mathrm{pH}$ meter.

5. Haugh unit (HU) diukur dengan cara menggunakan mesin Egg Multitester.

Menurut Panda (1996) Haugh Unit dapat dihitung menggunakan rumus:

$\mathrm{HU}=100 \log \left(\mathrm{H}+7,57-1,7 \mathrm{~W}^{0,37}\right)$

Keterangan :

$\mathrm{HU}:$ Haugh unit

$\mathrm{H}$ : Tinggi albumen (mm)

W : Bobot telur (g)

\section{Analisis data}

Data yang diperoleh dianalisa dengan analisis sidik ragam (Anova) apabila terdapat perbedaan yang nyata $(\mathrm{P}<0,05)$ diantara perlakuan dilanjutkan dengan uji jarak berganda dari Duncan's (Steel dan Torrie 1989).

\section{HASIL DAN PEMBAHASAN}

Berdasarkan penelitian yang telah dilakukan, diperoleh hasil dari pengaruh pemberian ransum komersial dengan tambahan grit kulit kerang sebagai sumber kalsium terhadap kualitas telur ayam Isa Brown umur 95 minggu yang tersaji pada (tabel 4) 
Tabel 4 Kualitas telur ayam isa brown umur 95 minggu yang diberi ransum komersial dengan tambahan grit kulit kerang sebagai sumber kalsium

\begin{tabular}{lccccc}
\hline \multirow{2}{*}{ Variabel } & \multicolumn{4}{c}{ Perlakuan $^{\mathbf{1})}$} & \multirow{2}{*}{ SEM $^{2)}$} \\
\cline { 2 - 4 } & P0 & P1 & P2 & P3 & \\
\hline Kualitas Eksterior : & & & & & 0,23 \\
Berat telur (g) & $64,32^{\mathrm{a}}$ & $64,72^{\mathrm{a}}$ & $64,90^{\mathrm{a}}$ & $64,68^{\mathrm{a}}$ & 0,98 \\
Indeks telur & $78,47^{\mathrm{a}}$ & $78,29^{\mathrm{a}}$ & $78,37^{\mathrm{a}}$ & $78,21^{\mathrm{a}}$ & \\
Kualitas interior : & & & & & 0,01 \\
Tebal kulit telur (mm) & $0,45^{\mathrm{a}}$ & $0,45^{\mathrm{a}}$ & $0,47^{\mathrm{a}}$ & $0,47^{\mathrm{a}}$ & 0,56 \\
Berat kulit telur (g) & $8,90^{\mathrm{a}}$ & $9,02^{\mathrm{a}}$ & $9,32^{\mathrm{a}}$ & $9,04^{\mathrm{a}}$ & 0,39 \\
Warna kuning telur & $7,80^{\mathrm{a}}$ & $7,80^{\mathrm{a}}$ & $8,00^{\mathrm{a}}$ & $7,80^{\mathrm{a}}$ & 0,90 \\
pH telur & $7,60^{\mathrm{a}}$ & $7,60^{\mathrm{a}}$ & $7,40^{\mathrm{a}}$ & $7,20^{\mathrm{a}}$ & 0,90 \\
Haught Unit (HU) & $80,04^{\mathrm{a}}$ & $80,62^{\mathrm{a}}$ & $80,47^{\mathrm{a}}$ & $80,60^{\mathrm{a}}$ & \\
\hline
\end{tabular}

Keterangan :

1). Ransum komersial (P0), Ransum komersial ditambah $1 \%$ grit kulit kerang (P1), Ransum komersial ditambah $2 \%$ grit kulit kerang (P2) dan Ransum komersial ditambah 3\% grit kulit kerang (P3)

2). SEM = Standard Error of the Treatment Mean

3). Nilai dengan huruf sama pada baris yang sama menunjukkan tidak berbeda nyata $(\mathrm{P}>0,05)$.

\section{Berat telur}

Rataan berat telur ayam Isa Brown yang mendapat ransum komersial dengan tambahan grit kulit kerang 2\% (P2) lebih tinggi sebesar 0,89\%, 0,28\% dan 0,34\% berbeda tidak nyata $(\mathrm{P}>0,05)$ dibandingkan perlakuan P0, P1 dan P3. Hasil rataan ini menunjukkan kandungan kalsium dalam ransum komersial dengan penambahan $2 \%$ dirasa sudah cukup untuk menambah berat telur, kelebihan kalsium akan di keluarkan oleh ayam dalam bentuk feses dan urin hal ini sejalan dengan pendapat Rolland et al. (1978) bahwa terpenuhinya kebutuhan kalsium dan konsumsi ransum pada periode produksi sesuai kebutuhan ayam petelur akan sangat menentukan besarnya massa kalsium cangkang yang pada akhirnya akan berpengaruh terhadap meningkatnya berat telur dan kualitas cangkang telur. Rataan berat telur ayam Isa Brown umur 95 minggu berkisar 62,9 g - 64,72 g hasil rataan ini tergolong berukuran besar hal ini didukung oleh BSN, (2008) yang membagi berat telur menjadi tiga yaitu kecil $(<50$ g/butir), sedang (50-60 g/butir) dan besar (>60 g/butir). Hasil ini disebabkan oleh beberapa fakor yaitu umur dan lingkungan, ayam pada awal periode bertelur menghasilkan telur yang ukurannya lebih kecil dan secara bertahap akan bertambah sejalan dengan semakin tuanya umur ayam. Hal ini didukung oleh Tugiyanti dan Iriyanti (2012) yang menyatakan semakin tua umur ayam maka perkembangan ovarium semakin sempurna dimana ovarium merupakan tempat pembentukan kuning telur persentase kuning telur sekitar 30-32\% dari berat telur, dan 
Yasmeen et al. (2008) menyatakan hal yang sama ayam petelur afkir menghasilkan bobot telur yang lebih tinggi dari ayam yang lebih muda. Selain faktor umur faktor lingkungan juga dapat mempengaruhi berat telur, genetik unggul tidak akan menampilkan keunggulan optimal jika tidak didukung oleh faktor lingkungan yang baik. Suhu lingkungan penelitian memiliki temperatur $23-26^{\circ} \mathrm{C}$ hal ini sudah sesuai dengan kebutuhan ayam petelur, pendapat ini didukung Priyatno (2004) yang menyatakan, suhu lingkungan untuk ayam petelur berkisar antara $21-27^{\circ} \mathrm{C}$.

\section{Indeks telur}

Indek telur yang dihasilkan ayam Isa Brown yang diberikan ransum komersial dengan tambahan grit kulit kerang sebanyak 1\% (P1) 2\% (P2) dan 3\% (P3) secara statistik berbeda tidak nyata $(\mathrm{P}>0,05)$ masing-masing lebih rendah $0,23 \%, 0,12 \%$ dan $0,26 \%$ dibandingkan dengan perlakuan P0. Rata-rata (Tabel 4) menunjukkan bahwa penambahan taraf kalsium pada ransum komersial tidak dapat mempengaruhi indeks telur, hasil ini dikarenakan ada beberapa ayam yang tidak dapat mengolah kalsium dengan baik, Sodak, (2011) menyatakan umur induk yang semakin tua akan menyebabkan kemampuan ayam untuk menyerap, memobilisasi, atau menyimpan cadangan nutrient, misalnya $\mathrm{Ca}$ berkurang. Rataan indeks telur ayam Isa Brown umur 95 minggu berkisar 78,21-78,67 rataan tergolong berukuran baik hal ini didukung oleh pendapat Murtidjo (1992) menyatakan bahwa indeks telur yang baik berkisar antara 70-79. Indek telur dapat digunakan untuk menentukan kualitas telur secara fisik, karena indek telur akan berpengaruh terhadap bentuk telur dan fungsi reproduksi (Tugiyanti dan Iriyanti 2012). Nilai indeks yang semakin tinggi akan menunjukkan bentuk telur yang semakin bulat namun semkin kecil nilai indeks maka bentuk telur semakin lonjong hal ini dikarenakan semakin tua umur ayam maka diameter ithmus semakin lebar maka bentuk telur yang dihasilkan semakin bulat (Pilliang, 1992 dan Septiawan, 2007).

\section{Tebal kulit telur}

Ayam yang diberikan ransum komersial dengan tambahan grit kulit kerang sebanyak $2 \%$ (P2), dan 3\% (P3) memiliki hasil rataan yang lebih tinggi 4,26\% dan 4,26\% dari perlakuan P0 dan P1 secara statistik berbeda tidak nyata $(\mathrm{P}>0,05)$, rataan tebal kulit telur berkisar 0,45 $\mathrm{mm}-0,47 \mathrm{~mm}$ (Tabel 4) hasil ratan yang diperoleh tergolong baik hal ini didukung oleh pendapat Sihombing et al. (2014) bahwa tebal kulit telur ayam ras yang normal berkisar antara 0,35-0,45 mm. Tebal kulit telur dipengaruhi oleh kandungan kalsium, phosfor serta umur ayam (Wahyu, 2004). Kandungan kalsium dan fosfor merupakan faktor yang mempengaruhi pada saat proses pembentukan kerabang telur yang terjadi di dalam uterus, hal 
ini sesuai dengan pernyataan Juliambarwati et al. (2012) yang menyatakan bahwa kandungan $\mathrm{Ca}$ dan $\mathrm{P}$ dalam pakan berperan terhadap kualitas kerabang telur karena dalam pembentukan kerabang telur diperlukan adanya ion-ion karbonat dan ion-ion $\mathrm{Ca}$ yang cukup untuk membentuk kerabang telur, semakin tinggi konsumsi kalsium maka kualitas kerabang telur semakin baik. Hasil penelitian ini menunjukakan penambahan 2-3\% kalsium dalam ransum dapat diolah oleh beberapa ayam dengan baik karena ayam yang berumur semakin tua akan kesulitan dalam menyimpan dan mengolah nutrient $\mathrm{Ca}$ dan $\mathrm{P}$ hal ini sejalan dengan Roland, (1986) menyatakan kualitas kerabang telur selaras dengan meningkatnya umur ayam, genetik dan pakan terutama imbangan $\mathrm{Ca}$ dan $\mathrm{P}$.

\section{Berat kulit telur}

Pemberian ransum komersial dengan tambahan grit kulit kerang 2\% (P2) menghasilkan rata-rata berat kulit telur tertinggi 9,32 g sedangkan P0, P1 dan P3 masing-masing sebesar $4,51 \%, 3,22 \%$ dan 3,00\% secara statistik tidak nyata lebih tinggi $(\mathrm{P}>0,05)$ dibandingkan perlakuan P2, hal ini diakibatkan adanya beberapa ayam yang tidak dapat memanfaatkan kalsium dengan baik dan penambahan kalsium $2 \%$ masih bisa dimanfaatkan oleh ayam untuk proses pembentukan kulit telur hal ini didukung oleh Rifaid (2018) yang menyatakan kualitas kerabang telur tergantung dari kemampuan ayam petelur dalam mengabsorbsi kalsium yang ada dalam pakan. Kualitas kulit telur ditentukan oleh tebal dan struktur kulit telur. Rataan berat kulit telur ayam Isa Brown umur 95 minggu berkisar 8,90 g - 9,32 g (Tabel 4.1) hasil rataan tergolong sangat tebal hal ini didukung oleh pendapat Amrullah (2004) yang menyatakan berat kulit telur yang baik sekitar 4,55-4,62 g. Hal ini dikarenakan terpenuhinya kebutuhan $\mathrm{Ca}$ dan $\mathrm{P}$ pada saat periode produksi dengan cara penambahan kulit kerang sebagai sumber kalsium pada ransum yang diberiakan secara ad libitum sehingga berat kulit telur yang dihasilkan tinggi hal ini didukung oleh Blakely dan Bade (1998) yang menyatakan grit memiliki kandungan kalsium yang cukup tinggi yaitu 38\% dapat dimanfaatkan oleh ayam secara optimal untuk pembentukan kulit telur, dan grit yang terbuat dari cangkang kerang merupakan sumber mineral seperti $\mathrm{Ca}, \mathrm{Mg}$, dan $\mathrm{P}$, kulit telur utamanya terdiri dari kalsium karbonat (97\%), sehingga seluruh telur mengandung 2,0-2,6g kalsium murni. Untuk membentuk kulit telur yang kuat harus disediakan kalsium dalam jumlah yang optimum.

\section{Warna kuning telur}

Warna kuning telur ayam Isa Brown yang diberikan ransum komersial dengan tambahan grit kulit kerang P2 mengasilkan rata-rata warna kuning telur tertinggi 8,00 sedangkan P0, P1 dan P3 memiliki persentase perbandingan yang sama sebesar 2,50\% lebih 
rendah, secara statistik warna kuning telur tidak nyata lebih tinggi $(\mathrm{P}>0,05)$ dibandingkan perlakuan P2. Rataan warna kuning telur berkisar 7,80-8,00 (Tabel 4), Amrullah (2003) menyatakan bahwa warna kuning telur yang bagus adalah dengan skor 10 skala Roche Yolk Colour Fan (RYCF). Hasil ini menunjukkan bahwa penambahan taraf kalsium pada ransum komersial tidak dapat mempengaruhi warna kuning telur serta ayam petelur mempenyai kemapuan yang berbeda dalam mengasilakn warna kuning telur hal ini didukung oleh Dobrzanski et al. (2007) yang menyatakan penambahan kalsium pada ayam petelur tidak mengakibatkan discolorasi pada kulit telur dan tidak berpengaruh pada warna kuning telur dan Castellini et al. (2006) menyatakan Setiap ayam mempunyai kemampuan berbeda untuk merubah pigmen karoten tersebut menjadi warna kuning telur. Kuning telur mengandung zat warna (pigmen) yang umumnya termasuk dalam golongan karotenoid yaitu xantofil, lutein, dan zeasantin serta sedikit betakaroten dan kriptosantin. Warna atau pigmen yang terdapat dalam kuning telur sangat dipengaruhi oleh jenis pigmen yang terdapat dalam ransum yang dikonsumsi (Winarno, 2002).

\section{pH telur}

Ayam yang diberikan ransum komersial dengan tambahan grit kulit kerang sebanyak $2 \%(\mathrm{P} 2)$, dan $3 \%(\mathrm{P} 3)$, yang menunjukan secara statistik hasil $\mathrm{pH}$ telur berbeda tidak nyata ( $\mathrm{P}>0,05)$ masing-masing lebih rendah 2,63\% dan 5,26\% dibandingkan dengan perlakuan P0 dan P1. Hasil (Tabel 4) rataan pH telur ayam Isa Brown umur 95 minggu berkisar 7,20-7,60 hasil rataan ini masih tergolong segar karena telur langsung diambil dan diteliti pada saat itu juga, hasil ini didukung oleh pendapat Belitz dan Grosch (2009) yang menyatakan telur ayam ras yang baru ditelurkan pHnya sekitar 7,6-7,9 tetapi selama penyimpanan dapat meningkat menjadi 9,5 atau lebih pada telur kualitas rendah. Kadar pH telur di pengaruhi oleh lama penyimpanan dan suhu (Wirapartha et al., 2019). Telur segar adalah telur yang masih memiliki kadar $\mathrm{pH}$ normal, yaitu 7, apabila kadar $\mathrm{pH}$ lebih dari 7 berarti telur sudah beberapa hari tersimpan (Wijaya et al,. 2019). Lestari et al. (2015) dan Sumayani (2019) menyatakan menurunnya kadar $\mathrm{pH}$ karena penguapan $\mathrm{CO}_{2}$ dari dalam telur akan semakin cepat pada suhu yang tinggi, hilangnya $\mathrm{CO}_{2}$ harus diganti dengan cara pemecahan ion bikarbonat yang mengakibatkan konsentrasi ion bikarbonat dalam putih telur menurun sehingga terjadi kerusakan pada jala-jala ovomucin dan merusak sistem buffer, akibatnya putih telur menjadi encer dan $\mathrm{pH}$ telur meningkat. 


\section{Haugh Unit (HU)}

Pemberian ransum komersial dengan tambahan grit kulit kerang sebagai sumber kalsium P1 menghasilkan rata-rata Haugh Unit telur tertinggi 80,62 sedangkan pada perlakuan P0, P2 dan P3 adalah 0,72\%, 0,19\% dan 0,03\% yang menunjukan secara statistik Haugh Unit telur tidak nyata lebih tinggi $(\mathrm{P}>0,05)$ dibandingkan perlakuan $\mathrm{P} 1$. Hal ini disebabkan oleh umur ayam yang semakin tua dan pada saat perjalanan membawa telur dari kandang menuju laboratorium Ternak Ungags Universitas Udayana Jimbaran untuk diteliti, telur mengalami suhu lingkungan yang berbeda sehingga nilai Haugh Unit tidak berbeda nyata hal ini didukung oleh pendapat Williams (1992) dan Widyantara et al. (2017) yang menyatakan Haugh Unit dipengaruhi umur ayam dan genotipnya, musim, kandungan nutrisi pakan, lama dan suhu selama penyimpanan. Umur ayam yang meningkat dan suhu lingkungan di atas $30^{\circ} \mathrm{C}$ menyebabkan penurunan nilai HU. Rataan Haugh Unit telur ayam Isa Brown umur 95 minggu berkisar 80,04-80,62 (Tabel 4) hasil rataan ini menunjukkan Haugh Unit mutu I atau telur sangat segar dikarenakan telur langsung diambil dan diteliti pada saat itu jaga hasil ini didukung oleh SNI, (2016) kesegaran telur dibedakan atas Mutu I, memiliki nilai HU>72, Mutu II, memiliki nilai HU 62-72 dan Mutu III, memiliki nilai $\mathrm{HU}<60$. Haugh Unit (HU) adalah satuan yang digunakan untuk mengukur kesegaran isi telur terutama putih telur, yang didasarkan ketebalan albuin. Semakin tinggi nilai HU dan semakin tinggi putih telur maka telur tersebut masih segar atau baru sebaliknya semakin rendah nilai HU maka kondisi albumen sangat encer dan mengembang. (Tugiayanti dan Irianti 2012).

\section{SIMPULAN DAN SARAN}

\section{Simpulan}

Pemberian ransum komersial dengan tambahan grit kulit kerang sebangai sumber kalsium sebanyak 1\%, 2\% dan 3\% pada ayam Isa Brown umur 95 minggu tidak meningkatkan berat telur, indeks telur, tebal kulit telur, berat kulit telur, warna kuning telur, pH telur dan Haugh Unit telur.

\section{Saran}

Berdasarkan hasil penelitian dapat disarankan kepada peternak untuk menggunakan grit kulit kerang supaya dapat mempertahankan kualitas telur ayam umur 95 minggu. 


\section{UCAPAN TERIMAKASIH}

Penulis mengucapkan terimaksih kepada Rektor Universitas Udayana Prof. Dr. dr. A. A. Raka Sudewi, Sp.S (K) dan Dekan Fakultas Peternakan Universitas Udayana bapak Dr. Ir I Nyoman Tirta Ariana, MS. Yang telah memberikan kesempatan serta fasilitias yang telah diberikan kepada penulis di Fakultas Peternakan Universitas Udayana. Kepada ibu dan bapak dosen pembing Prof. Dr.Ir. Gusti Ayu Mayani Kristina Dewi, MS dan Ir. I Wayan Wijana, MP yang telah memebrikan bimbingan dalam penulisan.

\section{DAFTAR PUSTAKA}

Amrullah, I.K. 2003.Nutrisi Broiler. Seri Beternak Mandiri. Lembaga Satu Gunung Budi. Bogor

Amrullah, I. K. 2004. Nutrisi AyamPetelur. Lembaga Satu GunungBudi. Bogor

Belitz, H. D and W. Grosch. 2009. Food Chemistry. Edisi 4 Revisi. Berlin

Bakely, J., Bade, D. H. 1998. Ilmu Peternakan. Gadjah Mada University Press. Yogyakarta

Budiansyah, B. 2010. Performan ayam broiler yang diberi ransum yang mengandung bungkil kelapa yang difermentasi ragi tape sebagai pengganti sebagian ransum komersial. Vol. 13 No. 5

Castellini, C. C.Mugnai, A.Dal B.2006.Effect of organic production system on broiler carcass and meat quality. Meat Sci,60:219-225.

Dewi, G. A. M. K. 2010. Pengaruh kalsium-asam lemak sawit (Ca-ALS) dan kalsium terhadap bobot telur, tebal kerabang dan kekuatan kerabang ayam petelur lohman. Majalah Ilmiah Peternakan. Majalah Ilmiah Peternakan13(1):20-35

Dobrzanski, Z. S. Opalinski, M. Korcynki, B. Walawska and T. Trziszka. 2007. Effect of calsium peroxide on the performance, egg quality as well as calcium and phosphorus concentrations in the blood serum of laying hens. Pol. J. Food Nutr. Sci. Vol. 57(4):107111.

Hargitai, R.Mateo R. Torok J.2011. Shell thickness and pore density in relation to shell colouration, female characteristics, and environmental faktors in the collared flycatcher ficedula albicollis.Journal Ornithology. 152: 579-588.

Hendrix Genetic Company. 2006. Layer Management Guide. Isa Brown, Ahendrix Genetic Company. Franc

Juliambarwati, M., R. Adi dan H. Aqni. 2012. Pengaruh penggunaan tepung limbah udang dalam ransum terhadap kualitas telur itik. Jurnal Sains Peternakan Indonesia.

Kurniasih, D. Rahmat, M. B. Handoko, C. R. Arfianto, A. Z. 2017. Pembuatan pakan ternak dari limbah cangkang kerang di desa Bulak Kenjaren Surabaya. Seminar Master. 25486527 
Lestari, D. Riyanti, Wanniatie, V. 2015. Pengaruh lama penyimpanan dan warna kerabang terhadap kualitas internal telur itik tegal. Jurnal Ilmiah Peternakan Terpadu. Vol. 3(1): $7-14$

Murtidjo. B. A. A. Daryanto, B. Sarwono. 1992. Telur Pengawetan dan Manfaatnya. Penebar Swadaya IKAPI. Jakarta

Panda, P. C. 1996. Textbook of Egg and Poultry Technology. Ram Printograph. Dehhi. India.

Pilliang, W. 1992. Peningkatan biovilabilitas dedak padi melalui proses fermentasi dengan Aspergillusniger. Pusat Penelitian dan Pengembangan Peternakan. Balai Peternakan Ternak Ciawi, Bogor.

Priyatno. 2004. Membuat Kandang Ayam. Cetakan ke-8. Penebar Swadaya, Jakarta.

Reid B.L. and Weber C. W. 1976. Calcium availability and trace mineral composition of feed grade Ca supplements. Poult. Sci. 55. 600-605

Rifaid.2018. Kualitas Dan Produksi Telur Berdasarkan Umur Dan Pakan Yang Digunakan.Skripsi.Universitas Islam Negeri Alauddin. Makassar

Rolland S. R. D. A. C.E. Putnam R.L. Hillburn. 1978. The relationship of age on ability of hens to maintain egg shell calcification when stressed with inadequate dietary calcium. Poult. Sci. 57: 1616-1621.

Roland, D. A. M. 1986. Egg shell quality IV.Oyster shell versus limestone and the importance of particle size or Ca source.World's Poult. Sci. 42 : 166 _ 177.

Septiawan, R. 2007. Respon produktivitas dan reproduktivitas ayam kampung dengan umur induk yang berbeda.Skripsi. Fakultas Peternakan. Institut Pertanian Bogor, Bogor

Suhardi, 2013. Struktur dan kualitas telur ayam local khas dayak bagi pengembangan dan pelestarian plasma nutflah ternak unggas. Vol 10 hal 67-73

Sultana, F., M.S. Islam, and M.A. Rhowlider. 2007. Effect of dietary calcium sources and levels on egg production and egg shell quality of javanese quail. International J. Poult Sci. 6(2):131-136

Sumayani, N. K. E. 2019. Kualitas telur ayam isa brown pasca divaksinasi egg drop syndrome dan diberi ransum dalam jumlah yang berbeda. eJurnal Tropika Peternakan Vol. 7 No. 1 Hal 169-184

Suprapto, W. Krismiyati, S. Suprijatna, E. 2012. Pengaruh penggunaan tepung kerabang telur ayam ras dalam ransum burung puyuh terhadap tulang tibia dan tarsus.Vol. 1. (1) : 7590

Standar Nasional Indonesia (SNI) 2016. Pakan Ayam Ras Petelur Bagian 6 Setelah Puncak Produksi (Layer post peak). Badan Standardisasi Nasional : Jakarta .

Standar dan Paten 2008. Telur Ayam Konsumsi. Badan Standardisasi Nasional (BSN).

Sodak JF. 2011. Karakteristik fisik dan kimia telur ayam pada dua peternakan di kabupaten Tulungagung, Jawa Timur skripsi. Institut Pertanian Bogor.

Steel, RGD dan JH Torrie. 1989. Prinsip dan Prosedur Statistika. Diterjemahkan oleh Bambang Sumantri. Gramedia Pustaka. Jakarta. 
Sihombing R, Kurtini T, Nova K. 2014. Pengaruh lama penyimpanan terhadap kualitas internal telur ayam ras pada fase kedua. Jurnal Ilmiah Peternakan Terpadu. 2(2):10-20

Tugiyanti E. Iriyanti N. 2012. Kualitas eksternal telur ayam petelur yang mendapat ransum dengan penambahan tepung ikan fermentasi menggunakan isolat produser antihistamin. Jurnal Aplikasi Teknologi Pangan. Vol. 1 No. 2. Fakultas Peternakan Universitas Jenderal Soedirman. Purwokerto.

Wahyu, J. 2004. Ilmu Nutrisi Unggas. Gajah Mada University Press: Jogjakarta

Widyantara, P. R. A. Dewi, G. A. M. Ariana, I. N. T. 2017. Pengaruh lama penyimpanan terhadap kualitas telur konsumsi ayam kampong dan ayam lohman brown. Majalah Ilmiah Peternakan. Vol. 20. No. 1

William, K.C. 1992. Some faktors affecting albumen quality with particular reference to Haugh unit score. World's Poultry Science Journal.48 : 5-16.

Wijaya, A. D. Munir. Kadir. M, J. 2019 Pengaruh topografi dan umur ayam yang berbeda terhadap ketebalan kerabang dan $\mathrm{pH}$ telur ayam ras petelur. Jurnal Bionature, Volume 20 , Nomor 1

Winarno, F.G. 2002. Kimia Pangan Dan Gizi. PT. Gramedia Pustaka Utama. Jakarta

Wirapartha, M. Wiyana, A. K. Dewi, G. A. M. K. Wijana, I. W. Pengaruh tray karton, kayu dan kawat terhadap kualitas telur ayam isa brown yang disimpan pada suhu kamar. 2019. Majalah Ilmiah Peternakan. Volume 22 Nomer 1

Yasmeen, P. S. Mahmood, M. Hassan, N. Akhtar and M. Yaseen. 2008. Comparative productive performance and egg characteristics of pullets and spent layers. Pakistan Vet. J., 2008, 28(1):5-8

Yuwanta, T. 2004. Dasar Ternak Unggas.Kanisius. Jakarta 